\title{
İşletmelerde Çok Boyutlu Performans Ölçme Modelleri ve Bir Araştırma ${ }^{1}$
}

\section{Multi-Dimensional Performance Measurement Models In Businesses And A Research}

\author{
AzZem ÖZKAN \\ Sevgi SÜMERLI SARIGÜL
}

$\ddot{O} Z$

Günümüzün rekabet koşullarında, işletmeleri başarıya taşıyacak bir etken olarak performans değerleme sistemi büyük öneme sahiptir. Bu sistemin başarılı bir biçimde uygulanabilmesi, işletmenin başarı grafiğinin devamlı takibini sağlayamaktadır. İsletmeler, başarılarının bütün unsurlarılyla değerlendirilmesini hedefleyen performans değerleme sistemine ilişskin finansman boyutunun beraberinde, finansman içerikli olmayan boyutunu da gözönünde bulundurmalıdirlar. Performans değerlendirmesinde, finansman göstergelerini esas alan performans değerleme sistemininin tek başına, işletmenin başarısını ortaya koyacak, kritik önemi bulunan bazı faktörleri ölçmede yeterli olamadığı görülmüş̧̈ür. Bu bağlamda gelenekselleşmiş performans değerleme sistemlerindeki yetersizlik ve eksikliklerin giderilmesi hedefi doğrultusunda, çok yönlü boyutları olan modellerin gelişstirilmesi üzerine yoğunlaşılmaya başlanmıştır. Bu çallş̧mada çok boyutlu performans ölçüm yöntemlerinden olan performans prizması modeli ile ilgili bir araştırmaya yer verilmiştir. Araştırmada performans prizması ve boyutları üzerine çeşitli değişkenlerin etkilerini araştırmak üzere bir model oluşturulmuştur. Model kapsamında çeşitli değişkenlerin algılanan performans prizması boyutları üzerine etkisi incelenmiştir. Elde edilen bulgulara göre bazı değişkenlerin (kurumsal sosyal sorumluluk, işletme kültürü, yenilikçilik ve müşteri odakllllk) performans prizması boyutları üzerine istatistiksel olarak anlamlı ve pozitif etkisi olduğu belirlenmiştir.

ANAHTAR KELIMELER

Performans, Performans Ölçümü, Çok Boyutlu Performans Değerleme Modelleri, Performans Prizması.

\begin{abstract}
In today's competitive conditions, performance appraisal system is of great importance as a factor that will lead the companies to success. Successful implementation of this system does not provide continuous follow-up of business success graph. Businesses should take into account the financial dimension of the performance appraisal system, which aims to evaluate their success with all elements, as well as the non-financial dimension. In the performance evaluation, the performance appraisal system, which is based on financial indicators, is not sufficient to measure some of the critical factors that will demonstrate the success of the enterprise. In this context, with the aim of eliminating the deficiencies and deficiencies in the traditional performance appraisal systems, it has been focused on the development of models with multidimensional dimensions. This study has been included the performance prism model of the multi-dimensional performance measurementmethods. In the research a model wascreated to investigate the effects of severalvariables on the performance prism and dimensions of prism. In the model the effects of variousvariables on perceived performance prismsizeswasexamined. According to the findingssomevariables (corporate social responsibility, corporateculture, innovation and customercentricity) verified that there is statistically significant and positive effect on the performance prismsizes.
\end{abstract}

KEYWORDS

Performance, Performance Measurement, Multi Dimensional Performance Evaluation Models, Performance Prism.

\begin{tabular}{|c|c|c|}
\hline & $\begin{array}{l}\text { Makale Geliş Tarihi / Submission Date } \\
\text { 08.08.2019 }\end{array}$ & $\begin{array}{l}\text { Makale Kabul Tarihi / Date of Acceptance } \\
\text { 20.12.2019 }\end{array}$ \\
\hline Atıf & \multicolumn{2}{|c|}{$\begin{array}{l}\text { Özkan, A. ve Sümerli Sarıül, S. (2020). İşletmelerde Çok Boyutlu Performans Ölçme Modelleri ve Bir Araştırma. } \\
\text { Selçuk Üniversitesi Sosyal Bilimler Meslek Yüksekokulu Dergisi, } 23 \text { (1), 54-72. }\end{array}$} \\
\hline
\end{tabular}

\footnotetext{
${ }^{1}$ Bu çalışma, "Geleneksel ve Çok Boyutlu Performans Değerleme Modelleri ve Bir Araştırma" başlıklı doktora tezinden üretilmiştir.

**Prof. Dr., Erciyes Üniversitesi, İiBF, e-posta: azzem@erciyes.edu.tr, ORCID: 0000-0001-5901-3314

*** Dr. Öğr. Üyesi, Kayseri Üniversitesi MYO, ssumerli@erciyes.edu.tr, ORCID: 0000-0002-3820-6288
} 


\section{GİRIŞ}

İşletmelerin varlığını sürdüremesi ve ekonomik oarak büyümesi diğer işletmelerle olan rekabet gücüyle doğrudan bağlantılıdır. Bu nedenle işletmelerin rekabet gücüne ilişkin en uygun tespitin yapılabilmesi de ancak sağlıklı bir performans ölçümü ile mümkün olabilir.

Yabancı kökenli bir sözcük olan performans Türkçe’ye “edim” olarak çevrilmiştir. Günlük konuşma ve yazı dilinde "edim"den ziyade "performans" olarak kullanılmaktadır (Çalık, 2003, 7). Performans kavramının Türk Dil Kurumu sözlüğündeki anlamı; bir faaliyetin gerçekleştirilmesinde başarı göstergesi, bir sunum veya gösterinin gerçekleştirilebilme yeterliliği, bir mekanizmanın çalışma şekli, bir kişinin konuşma şekli, bir işi yapabilme yeteneği ya da bir işi yaparken gösterilen efordur (www.tdkterim.gov.tr).

Genel olarak işletme amaçlarının gerçekleştirilmesi için gösterilen tüm çabaların değerlendirilmesi olarak da ele alınabilen performans, işletmenin gerçekleştirdiği etkinliklerin sonuçlarının ölçülmesidir (Öztürk, 2009, 4). Başka bir tanımda performans için "amaçlanan bir hedefin ne kadarının başarılabildiğinin nicel (miktar) ve nitel (kalite) açıdan ifadesidir" denilmektedir (Baş ve Artar, 1991, 13; Şentürk, 2005, 23; Tınaz, 2005, 77). O halde en genel anlamıyla performans, bir işi yapan bir bireyin, bir grubun ya da bir teşebbüsün, o işle amaçlanan ve planlanan hedefe yönelik olarak, belirlenmiş bir zaman diliminde amaçlanan ve hedeflenen noktaya ne kadar varabildiğinin nicel ve nitel olarak belirleyen bir kavramdır (Akal, 2005, 17).

Performans ölçümü, yönetimin kontrol işlevinin en önemli faaliyetidir (Coşkun, 2006, 120). Performans ölçümü ve değerlendirme, işletme yöneticisinin işletme üzerindeki etkinliğini göstermesi bakımından son derece önemli bir konudur (Parker, 2000, 63). Performansın ölçülmesi, işletmelerin hedeflerine ulaşma konusunda ne kadar mesafe kat ettiklerini izlemelerine imkân sağladığı gibi, yöneticilerine de organizasyonel ve yönetsel kararlarında çok önemli bir veri oluşturmaktadır.

Günümüze kadar pek çok performans ölçme yöntemi geliştirilmiştir. Bu yöntemlerin her birinin ortak özelliği, kendilerinden önce uygulanan yöntemlerinin eksikliklerini gidererek, performansın daha doğru ve objektif bir biçimde ölçülmesini sağlamaktır.

\section{KAVRAMSAL ÇERÇEVE}

\section{1. Çok Boyutlu Performans Ölçme Modelleri}

Günümüz rekabet ortamında yönetimin ihtiyaçlarına tam olarak cevap verebilecek bir performans ölçüm sisteminin olmadığı söylenebilir. Zira, birçok işletme tarafından yalnızca finansman tabanlı performansa ilişkin ölçme modellerinin kullanılmakta olduğu ve genel olarak kısa dönemi kapsayacak biçimdeki performansa yönelik göstergelere bağlı kaldığı ve işletme performansını etkileyen faktörler arasındaki dengeleri kuramadığı görülmektedir. Performansa dayalı ölçme yöntemlerinin gelenekselleşmiş olanlarını kullanan işletmelerde karşı karşıya kalınan bu tür problemlerin çözülebilmesi için katkı sağlayacak olan çok boyutlu performans ölçüm modelleri geliştirilmiştir (Ağca, 2005, 149; Ağça, 2009, 51-66). Söz konusu çok boyutlu modellerin literatür kapsamında en fazla dikkat çekenleri şekildedir ve bu modeller kapsamında bulunan boyutlar Tablo 1.1'de sunulmuştur: 
Tablo 1.1. Çok Boyutlu Performans Değerleme Modelleri ve Boyutları

Kaynak: Elitaş ve Ağca, 2006, 367; Ağça, 2009, 56; Erserim, 2011, 25’den yararlanılarak tarafımızdan düzenlenmiştir.

\begin{tabular}{|c|c|c|c|c|c|c|c|c|c|c|c|c|c|c|c|}
\hline \multirow{3}{*}{ 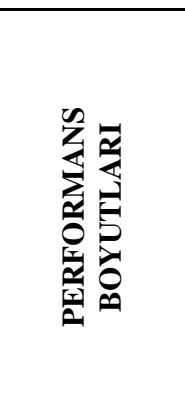 } & \multicolumn{15}{|c|}{ ÇOK BOYUTLU PERFORMANS DEĞERLEME MODELLERİ } \\
\hline & $\begin{array}{c}\text { Süreç } \\
\text { Mühendis- } \\
\text { leri1930 }\end{array}$ & $\begin{array}{l}\text { Keegan } \\
\text { vd. } 1989\end{array}$ & $\begin{array}{l}\text { Dixon } \\
\text { vd, } \\
1990\end{array}$ & $\begin{array}{l}\text { Lynch ve } \\
\text { Cross } \\
1991\end{array}$ & $\begin{array}{c}\text { Fitzgerald } \\
\text { vd. } 1991\end{array}$ & $\begin{array}{l}\text { Kaplan } \\
\text { ve } \\
\text { Norton } \\
1992, \\
1996\end{array}$ & $\begin{array}{c}\text { Skandia } \\
\text { Şirketi } \\
1994\end{array}$ & $\begin{array}{l}\text { Ghalayini } \\
\text { vd. } 1997\end{array}$ & $\begin{array}{c}\text { Bititci } \\
\text { vd. } 1997\end{array}$ & $\begin{array}{l}\text { Atkinson } \\
\text { vd. } 1997\end{array}$ & $\begin{array}{c}\text { Medori ve } \\
\text { Steeple } \\
2000\end{array}$ & $\begin{array}{l}\text { Chennel } \\
\text { vd. } 2000\end{array}$ & $\begin{array}{r}\text { Laitinen } \\
2002\end{array}$ & $\begin{array}{c}\text { Parida } \\
\text { ve } \\
\text { Kumar } \\
2006\end{array}$ & $\begin{array}{l}\text { Neely vd. } \\
2000\end{array}$ \\
\hline & $\begin{array}{c}\text { Kumanda } \\
\text { Paneli }\end{array}$ & $\begin{array}{c}\text { Perf. } \\
\text { Ölçüm } \\
\text { Matrisi }\end{array}$ & $\begin{array}{l}\text { Perf. } \\
\text { Ölçümm } \\
\text { Anketi }\end{array}$ & $\begin{array}{c}\text { Perf. } \\
\text { Piramidi }\end{array}$ & $\begin{array}{c}\text { Sonuçlar } \\
\text { ve } \\
\text { Belirleyicil } \\
\text { er } \\
\text { Modeli } \\
\end{array}$ & $\begin{array}{l}\text { Perf. } \\
\text { Karnesi }\end{array}$ & $\begin{array}{l}\text { Skandia } \\
\text { Klavuzu }\end{array}$ & $\begin{array}{c}\text { Büttünleşik } \\
\text { Dinamik } \\
\text { Perf. } \\
\text { Ölçüm } \\
\text { Sistemleri } \\
\end{array}$ & $\begin{array}{l}\text { Bütünle- } \\
\text { şikEnteg } \\
\text { re Perf. } \\
\text { Ölçüm } \\
\text { Sistemi }\end{array}$ & $\begin{array}{c}\text { Paydas } \\
\text { Temelli } \\
\text { Perf. } \\
\text { Değerleme } \\
\text { Modeli } \\
\end{array}$ & $\begin{array}{c}\text { Bütünleşik } \\
\text { Perf. } \\
\text { Ölçümm } \\
\text { Şablonu }\end{array}$ & $\begin{array}{c}\text { Organi- } \\
\text { zasyonel } \\
\text { PD. } \\
\text { Modeli }\end{array}$ & $\begin{array}{c}\text { KOBi’ler } \\
\text { için } \\
\text { Entegre } \\
\text { Perf. } \\
\text { Ölçüm } \\
\text { Modeli } \\
\end{array}$ & $\begin{array}{c}\begin{array}{c}\text { Sürdürül } \\
\text { ebilir.Pe } \\
\text { rf. } \\
\text { Ölçüm } \\
\text { Modeli }\end{array} \\
\end{array}$ & $\begin{array}{c}\text { Perf. } \\
\text { Prizması } \\
\text { Modeli }\end{array}$ \\
\hline Finansal & $\sqrt{ }$ & $\sqrt{ }$ & $\sqrt{ }$ & $\sqrt{ }$ & $\sqrt{ }$ & $\sqrt{ }$ & $\sqrt{ }$ & $\sqrt{ }$ & $\sqrt{ }$ & $\sqrt{ }$ & $\sqrt{ }$ & $\sqrt{ }$ & $\sqrt{ }$ & $\sqrt{ }$ & $\sqrt{ }$ \\
\hline Müşteri & $\sqrt{ }$ & $\sqrt{ }$ & $\sqrt{ }$ & $\sqrt{ }$ & & $\sqrt{ }$ & $\sqrt{ }$ & $\sqrt{ }$ & $\sqrt{ }$ & $\sqrt{ }$ & & $\sqrt{ }$ & & $\sqrt{ }$ & $\sqrt{ }$ \\
\hline Pazar & & $\sqrt{ }$ & & $\sqrt{ }$ & & & & & $\sqrt{ }$ & & & $\sqrt{ }$ & $\sqrt{ }$ & & \\
\hline $\begin{array}{c}\text { Ürün ve } \\
\text { Süreçlerin } \\
\text { Kalitesi }\end{array}$ & $\sqrt{ }$ & & & $\sqrt{ }$ & $\sqrt{ }$ & $\sqrt{ }$ & $\sqrt{ }$ & $\sqrt{ }$ & $\sqrt{ }$ & $\sqrt{ }$ & $\sqrt{ }$ & $\sqrt{ }$ & $\sqrt{ }$ & & $\sqrt{ }$ \\
\hline $\begin{array}{c}\text { Ürün ve } \\
\text { Süreçlerin } \\
\text { Hızı }\end{array}$ & $\sqrt{ }$ & $\sqrt{ }$ & & $\sqrt{ }$ & & $\sqrt{ }$ & $\sqrt{ }$ & $\sqrt{ }$ & $\sqrt{ }$ & $\sqrt{ }$ & $\sqrt{ }$ & $\sqrt{ }$ & & & $\sqrt{ }$ \\
\hline $\begin{array}{c}\text { Etkinlik/ } \\
\text { Verimlilik } \\
\text { (Kaynaklar) }\end{array}$ & & & & $\sqrt{ }$ & $\sqrt{ }$ & $\sqrt{ }$ & & & $\sqrt{ }$ & & & & $\sqrt{ }$ & & $\sqrt{ }$ \\
\hline Esneklik & & & & $\sqrt{ }$ & $\sqrt{ }$ & & & $\sqrt{ }$ & $\sqrt{ }$ & & $\sqrt{ }$ & & & & $\sqrt{ }$ \\
\hline Yenilik & & $\sqrt{ }$ & & & $\sqrt{ }$ & $\sqrt{ }$ & $\sqrt{ }$ & & & & & & & & $\sqrt{ }$ \\
\hline $\begin{array}{l}\text { Öğrenme ve } \\
\text { Gelișme }\end{array}$ & & $\sqrt{ }$ & $\sqrt{ }$ & & $\sqrt{ }$ & $\sqrt{ }$ & $\sqrt{ }$ & & & & $\sqrt{ }$ & & & $\sqrt{ }$ & $\sqrt{ }$ \\
\hline Çalışanlar & & & $\sqrt{ }$ & & & $\sqrt{ }$ & $\sqrt{ }$ & $\sqrt{ }$ & $\sqrt{ }$ & $\sqrt{ }$ & & $\sqrt{ }$ & & $\sqrt{ }$ & $\sqrt{ }$ \\
\hline $\begin{array}{l}\text { Vizyon/ } \\
\text { Strateji }\end{array}$ & & & & $\sqrt{ }$ & & $\sqrt{ }$ & & & $\sqrt{ }$ & & & $\sqrt{ }$ & & & $\sqrt{ }$ \\
\hline Rekabet & & $\sqrt{ }$ & $\sqrt{ }$ & & $\sqrt{ }$ & & & & $\sqrt{ }$ & & & $\sqrt{ }$ & $\sqrt{ }$ & & $\sqrt{ }$ \\
\hline $\begin{array}{c}\text { Sosyal } \\
\text { Sorumluluk } \\
\text { ve Dişsal } \\
\text { Çevre }\end{array}$ & & $\sqrt{ }$ & $\sqrt{ }$ & & & & & & $\sqrt{ }$ & $\sqrt{ }$ & & $\sqrt{ }$ & & $\sqrt{ }$ & \\
\hline
\end{tabular}


Performans ölçme yaklaşımları literatürde temel olarak farklı gruplandırmalara tabi tutulmakla beraber bu çalışmada çok boyutlu performans ölçme modellerinden performans prizması modeli ele alınacaktır.

\subsection{Performans Prizması}

Performans Prizması modeli 2000 yılında Adams ve Neely tarafından Performans Karnesi'nin (PostMerger Integration, PMI) değerlendirmede yetersiz kalmasından dolayı ortaya konulmuş performans içerikli bir ölçüm modelidir (Adams and Neely; 2000, 20). Söz konusu Performans Prizmasının, birçok değerleme yönteminin aksine, performans değerleme sürecinde işletmenin paydaşlarının kimler olduğu ve ne istedikleriyle başladığı görülmektedir (Neely; Bourne; Kennerley, 2000, 1119).

Yöntem, diğer yöntemler tarafından önem verilen müşterilerve sermayedarlara ilave olarak çalışanları, tedarikçileri ve kamunun oluşturduğu diğer paydaşları da önemli bulmaktadır. Söz konusu modelin diğer modellere göre farklı tarafi; önceliğin işletmenin stratejik yaklaşımına değil, paydaşlarına verilmesini ve (Adams and Neely; 2000, 20) paydaşların istek ve ihtiyaçlarının öncelikli olarak ele alınılması gerektiğini belirterek stratejilerin daha sonra formüle edilmesini savunmaktadır (Neely; Adams; Crowe, 2001, 6).

$\mathrm{Bu}$ modelin temel özelliği başarılı bir performans ölçüm sisteminin bağlı olduğu tüm kritik faktörleri kapsayacak şekilde tasarlanmış olmasıdır. Şekil 1.1.'de de görülmekte olduğu gibi performans prizmasının beş yüzeyi bulunmakta ve bu yüzeyler de performansa ilişkin beş boyutu temsil etmektedir. Prizmanın en üstü paydaşlar açısından tatmin boyutunu (veya memnuniyet düzeyini) gösterirken, taban kısmında da paydaşların katkısına ilişkin boyut bulunmaktadır. Üst ve alt yüzeylerin arasında yer alan üç ayrı yüzey ise art arda; stratejileri, süreçleri (işlemleri) ve kabiliyetleri (yetkinlikleri) içermektedir (Şekil 1.2.) (Adams and Neely, 2000, 20-23; Neely; Adams; Crowe, 2001, 12; Tangen, 2004, 733-734).

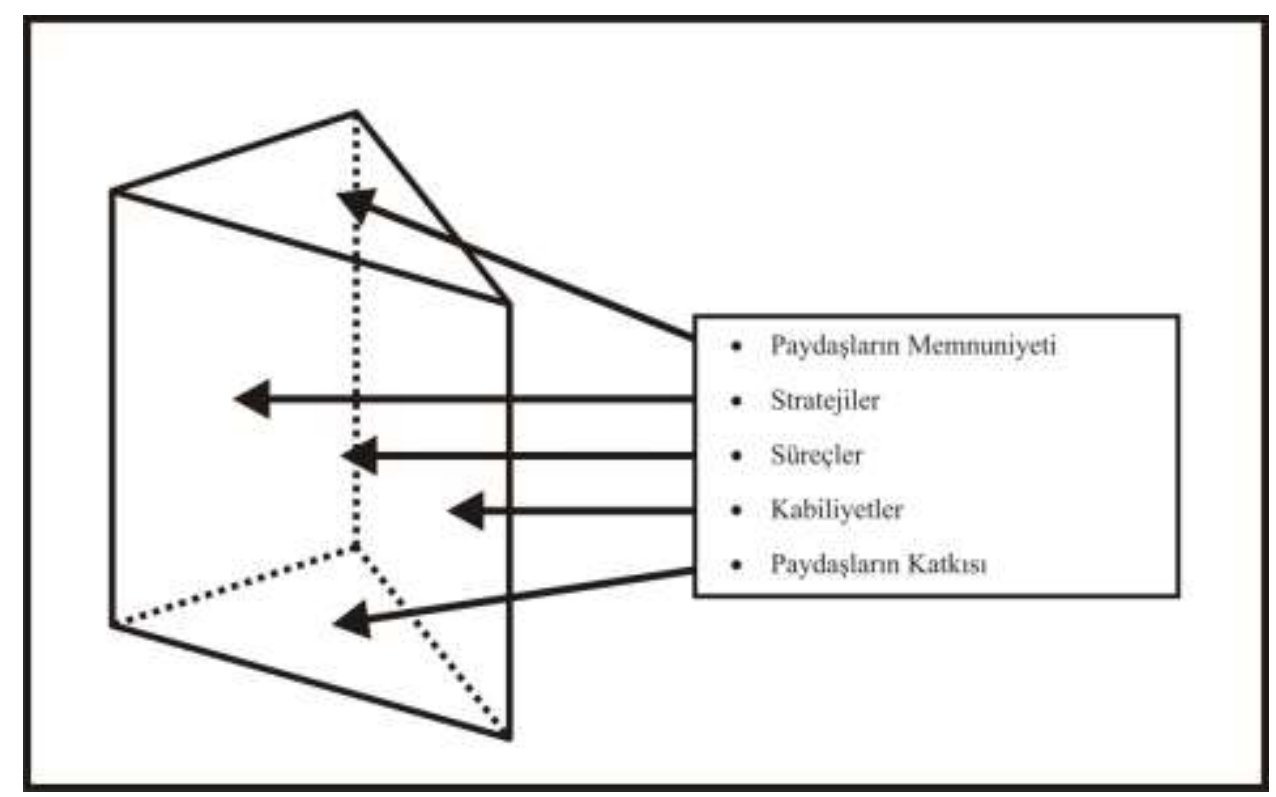

Şekil 1.1. Performans Prizmasının Beş Yüzü

Kaynak: Neely; Adams; Crowe, 2001, 12'den yararlanılmıştır.

\subsection{Performans Prizmasının Boyutları}

Performans Prizması, içeriğindeki beş boyut bakımından aşağıda yer alan sorular için cevap arayışını öngörmekte olan bir modeldir (Neely and Adams, 2001, 7-15). Bunlar (Neely; Adams; Crowe, 2001, 6-7; Tangen, 2004, 733);

Paydaşların Memnuniyeti Boyutu: İşletmenin anahtar paydaşları kimlerdir ve onların ihtiyaçları ve beklentileri nelerdir?

Stratejiler Boyutu: Paydaşların ihtiyaçları ve beklentilerinikarşılamakiçin işletmelerin ihtiyaç duyduğu stratejiler nelerdir?

Süreçler (İşlemler) Boyutu: İşletmenin stratejilerini gerçekleştirebilmek için ihtiyaç duyulan süreçler nelerdir? 
Yetkinlikler/KabiliyetlerBoyutu: Stratejileri gerçekleştirecek süreçleri işletmek ve geliştirmek için işletmelerin ne tür yetkinliklere/kabiliyetlere ihtiyacı vardır?

Paydaşların Katkısı Boyutu: İşletmenin paydaşlardan beklentileri nelerdir?

İşletme, yukarıdaki soruların cevaplarını vererek kendisine özgüleştirdiği bir performans değerleme modelini elde edebilmektedir.

İşletmedeki örgütsel performansın yönetilmesi için beş boyutun biraraya gelmesi ve kapsamlı entegre bir yapının ortaya çıkması gerekmektedir (Neely; Adams; Kennerley, 2002b, 3-7).

\section{ISSLETME PERFORMANSININ ÖLÇÜMÜNDE PERFORMANS PRIZMASI MODELİNE ILLIŞKİN BİR ARAŞTIRMA}

Bu bölümde çalışmanın uygulama kısmına yer ayrılmıştır. Bu bölümde öncelikle araştırmanın amacı ve önemi, örneklemi, sınırları, araştırma verilerinintoplanması, araştırmanın modeli ve hipotezleri hakkında bilgi veriecek daha sonra yapılan analizler doğrultusunda bulgularının değerlendirmesi yapılacaktır.

\subsection{Araştırmanın Amacı}

$\mathrm{Bu}$ araştırmanın amacı; çok boyutlu performans ölçüm modellerinden Performans Prizması modelini kullanarak çeşitli faktörlerin işletme performansıyla ilişkisini ve bu faktörlerin işletme performansını etkileyip etkilemediğini ortaya koymaktır.

\subsection{Araştırmanın Önemi}

Performans Prizması modelinin genel olarak literatürde ve ülkemizde imalat işletmelerinde uygulanmadığı, yurt dişında ise daha çok hizmet ve sivil toplum kuruluşlarındauygulandığı görülmektedir.

Bu bakımdan araştırmanın teorik ve pratik açılardan, üretim ve hizmet alanlarında faaliyetler göstermekte olan işletmelerin uygulamaları için katkı sağlayacağı düşünülmektedir. Ayrıca araştırmacıların gelecekte bu konuda yapacakları çalışmalara da bazı yönlerden temel teşkil edeceği beklenmektedir.

\subsection{Metodoloji}

$\mathrm{Bu}$ bölümde araştırmamızın evreni ve örneklemi, araştırmanın modeli, kullanılan ölçekler, araştırma ile ilgili bulgular ve değerlendirilmesine yer verilecektir.

\subsubsection{Araştırmanın Evreni ve Örneklemi}

Araştırmanın evrenini Kayseri Organize Sanayi Bölgesi’nde faaliyet gösteren küçük ve orta büyüklükteki (KOBİ) işletmeler oluşturmaktadır. Kayseri Organize Sanayi Bölge Müdürlügü’ndan alınan verilere göre araştırma evrenine dahil olabilecek çeşitli sektörlerde faaliyet gösteren 803 işletme bulunmaktadır. Ancak bu işletmelerin 165 tanesinin çalışan sayısının 1-7 kişiden oluşması dolayısıyla mikro işletme kapsamında olduğu, 38 işletmenin faaliyetine son verdiği, 7 işletmenin ise sadece depo olarak faaliyet gösterdiği tespit edilmiştir. $\mathrm{Bu}$ durumda ana kütlemizin 593 işletme olduğu tespit edilmiştir.

Araştırma evreninde 593 işletme bulunmaktadır. Bunlardan seçilecek örneklemin miktarı aşağıdaki formül ile hesaplanmış ve 185 anket gerektiği tespit edilmiştir. Söz konusu formül şöyledir (Yazıcıŏglu ve Erdoğan, 2004, 50):

$$
n=\frac{N \cdot \stackrel{2}{\sigma} \cdot Z \alpha}{(N-1) \cdot d^{2}}
$$

Araştırma sonucunda örneklem tespiti için ${ }_{+}-0.05$ örnekleme hatası ile $\% 90$ başarı sağlamak için gerekli olan 185 adet anketten 180 firmaya ulaşılmıştır.

\subsubsection{Araştırmanın Modeli}

Araştırmanın modeli, çok boyutlu performans değerleme yöntemlerinden Adams ve Neely tarafindan 2000'de gerçekleştirilen "Performans Prizması" ölçme modelinin esas alınmasıyla oluşturulmuştur.

Performans prizması birbiri ile ilişkili olan Paydaş Memnuniyeti, Stratejiler, Süreçler (İşlemler), Yetkinlikler (Kabiliyetler) ve Paydaş Katkısı boyutu olmak üzere 5 ana performans boyutundan oluşmaktadır. Ayrıca bu ana boyutlara ait çeşitli alt göstergeleri de bulunmaktadır. Tablo 2.1'de performans prizmasının ana boyutları ve bu ana boyutlara ilişkin alt göstergeler toplu halde görülmektedir. 
Model: Çeşitli değişkenlerin algılanan performans prizması boyutları üzerine etkisi

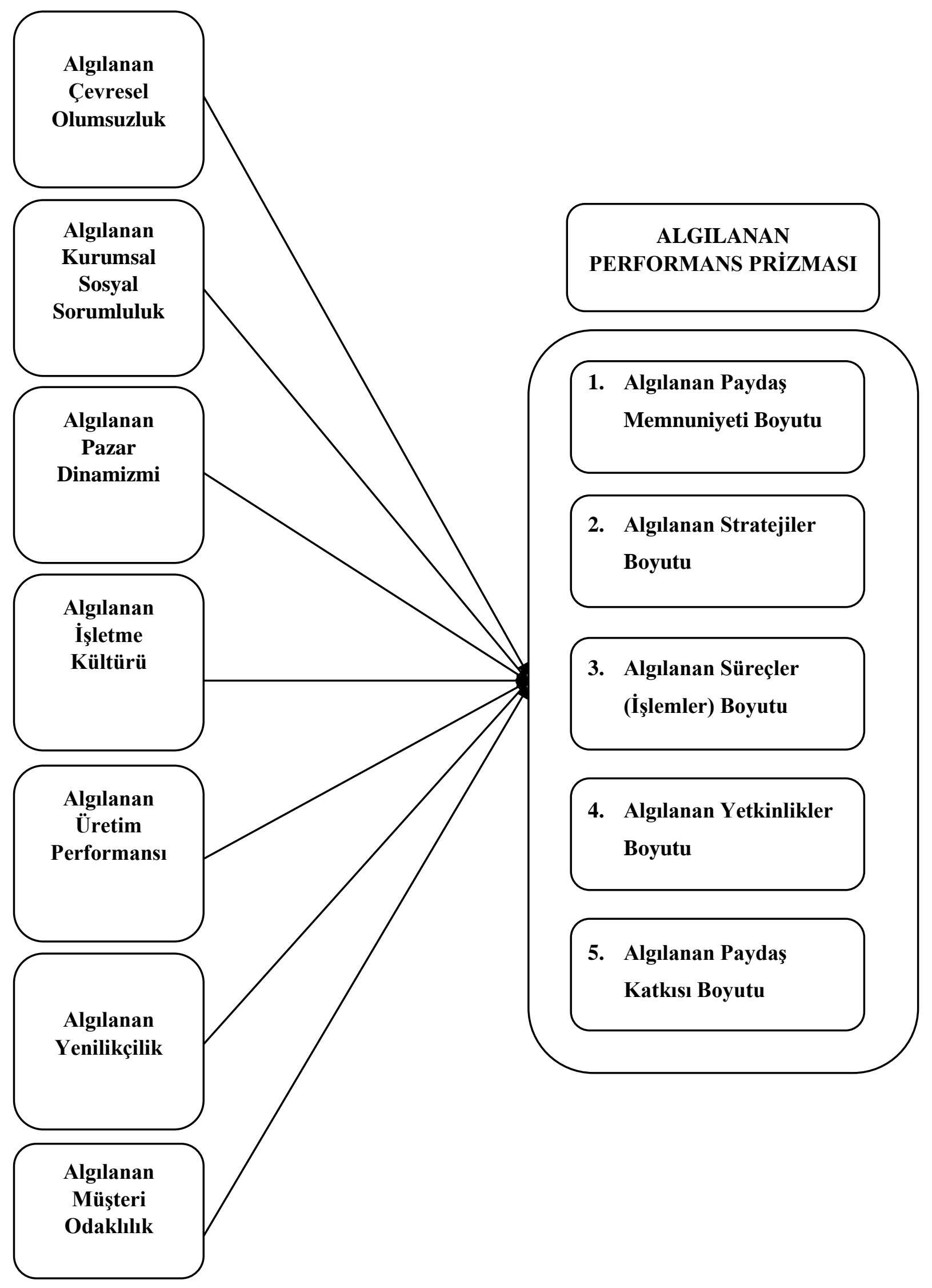


Tablo 2.1. Performans Prizmasının Boyutları ve Alt Göstergeleri

\begin{tabular}{|c|c|c|}
\hline Müşterilerin Memnuniyeti & \multirow{6}{*}{$\begin{array}{c}\text { Algllanan Paydaş } \\
\text { Memnuniyeti Boyutu }\end{array}$} & \multirow{26}{*}{ 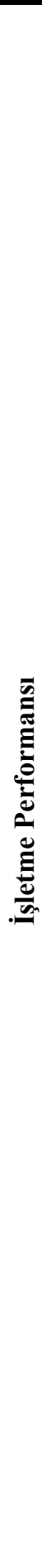 } \\
\hline Çalışanların Memnuniyeti & & \\
\hline Yatırımcıların Memnuniyeti & & \\
\hline Tedarikçilerin Memnuniyeti & & \\
\hline İdari ve Yasal Düzenleyicilerin Memnuniyeti & & \\
\hline Toplumun Memnuniyeti & & \\
\hline İşletme Stratejisi Oluşturma & \multirow{6}{*}{$\begin{array}{c}\text { Algılanan Stratejiler } \\
\text { Boyutu }\end{array}$} & \\
\hline İş Birimleri (Bölüm) Oluşturma & & \\
\hline Marka Stratejisi Oluşturma & & \\
\hline Ürün Stratejisi Oluşturma & & \\
\hline Hizmet Stratejisi Oluşturma & & \\
\hline Stratejileri Hayata Geçirmek İçin Planlama Yapma & & \\
\hline Yeni Ürün ve Hizmet Geliştirme & & \\
\hline Üretim Taleplerini Yerine Getirme Kabiliyeti & & \\
\hline Müşteri Taleplerini Yerine Getirme Kabiliyeti & (İslemler) & \\
\hline Stratejik Planlar ve Programlar Geliştirme & & \\
\hline Çalışanlarla İlgili Yetkinlikler & & \\
\hline Fiziksel Olanaklarla İlgili Yetkinlikler & Algılanan Yetkinlikler & \\
\hline Teknoloji İle İlgili Yetkinlikler & Boyutu & \\
\hline Altyapı (Yapılanma) Stratejileri İle İlgili Yetkinlikler & & \\
\hline Müşterilerin Katkısı & & \\
\hline Çalışanların Katkısı & & \\
\hline Yatırımcıların Katkısı & Algılanan & \\
\hline Tedarikçilerin Katkısı & $\begin{array}{c}\text { Paydaş Katkısı } \\
\text { Boyutu }\end{array}$ & \\
\hline İdari ve Yasal Düzenleyicilerin Katkısı & & \\
\hline Toplumun Katkıs1 & & \\
\hline
\end{tabular}

Kaynak: Adams and Neely, 2000, 21-23; Neely; Adams; Crowe, 2001, 12; Neely; Adams; Kennerley, 2002a, 166-181'den yararlanılarak oluşturulmuştur.

\subsubsection{Araştırmada Kullanılan Ölçekler}

Araştırma için seçilen modelin test edilmesine yönelik olarak; değişkenlerin ölçümü ve katılımcıların algılarının belirlenmesi amacıyla kullanılacak veri toplamak için uygulanan anketin oluşturulmasında, geçerlilik ve güvenilirlikleri daha önceki çalışmalarda test edilmiş ölçekler kullanılmıştır. Söz konusu ölçekler şöyledir: 
Çevresel Olumsuzluk Ölçeği: Araştırmada algılanan çevresel olumsuzluğu ölçmek üzere Covin ve Slevin (1986)'in geliştirerek oluşturdukları 5 ifade bulunan bir ölçekten yararlanılmıştır.

Kurumsal Sorumluluk Ölçeği: İşletmelerin algılanan kurumsal sosyal sorumluluğunu (KSS) ölçmek için Türker (2009) tarafından 5'li likert ölçeğine göre geliştirilmiş 18 ifadeden oluşan güncel bir ölçekten yararlanılmıştır.

Pazar Dinamizmi Ölçeği: Araştırmada algılanan pazar dinamizminin ölçülmesi için, literatürde bu alanda çalışmaları bulunan Zahra ve Garvis (2000), Simmerly ve Li (2000) ve Goll ve Rasheed (1997)'den yararlanılarak 4 ifadeden oluşan bir ölçek kullanılmıştır.

İşletme Külltürü Ölçeği: Algılanan işletme kültürünü ölçmek için Yılmaz vd. (2005) tarafindan geliştirilmiş 5 ifadeden oluşan bir ölçek kullanılmıştır.

Üretim Performansı Ölçeği: Algılanan üretim performansını ölçmek için geliştirilmiş 6 ifadeden oluşan bir ölçekten yararlanılmıştır. Bu bölümdeki ölçekler Gattorna vd. (1991), Emerson ve Grimm (1996), Morash vd. (1996), Murphy ve Poist (1996) ve Ellinger vd. (2000)'nin çalışmalarından esinlenerek hazırlanmıştır.

Yenilikçilik Ölçeği: Yenilikçiliği ölçmek için geliştirilmiş 5 ifadeden oluşan bir ölçekten yararlanılmıştır. Ölçek Hult vd. (2003), Garg vd. (2003), Zehir ve Özşahin (2006)'nin çalışmalarından esinlenerek hazırlanmıştır.

Müşteri Odaklılık Ölçeği: Algılanan müşteri odaklılığın ölçülmesi amacıyla Deshpande ve Farley (1998)'in geliştirdikleri 8 ifadenin yer aldığı bir ölçekten faydalanılmıştır.

Araştırmada kullanılan ölçeklerin güvenirlik değerleri toplu olarak aşağıdaki tabloda verilmiştir.

Tablo 2.2. Ölçeklerin Güvenirlik Değerleri

\begin{tabular}{|l|c|c|}
\hline$\underline{\text { Değiskenler }}$ & $\frac{\begin{array}{c}\text { İfade / } \\
\text { Soru Savıları }\end{array}}{\mathbf{5}}$ & $\frac{\text { Cronbach's Alfa }}{\frac{\text { Değerleri }}{\mathbf{0 , 6 7}}}$ \\
\hline Algılanan Çevresel Olumsuzluk & 18 & $\mathbf{0 , 8 8}$ \\
\hline $\begin{array}{l}\text { Algılanan Kurumsal Sosyal } \\
\text { Sorumluluk }\end{array}$ & $\mathbf{5}$ & $\mathbf{0 , 8 1}$ \\
\hline Algılanan Pazar Dinamizmi & $\mathbf{5}$ & $\mathbf{0 , 8 7}$ \\
\hline Algılanan İşletme Kültürü & $\mathbf{6}$ & $\mathbf{0 , 8 3}$ \\
\hline Algılanan Üretim Performansı & $\mathbf{5}$ & $\mathbf{0 , 8 4}$ \\
\hline Algılanan Yenilikçilik & $\mathbf{8}$ & $\mathbf{0 , 8 5}$ \\
\hline Algılanan Müşteri Odaklıık & \\
\hline
\end{tabular}

*Nunnally (1978)'e göre ölçek güvenilirliğinin sağlanabilmesine yönelik olarak alfa güvenilirlik katsayısının 0,70 ve daha üzerinde olması gerektiği görüşündedir. Robinson vd. (1991)'nin görüşlerine göre ise keşifsel faktör analizi için bu değeri 0,60 kabul etmenin mümkün olduğunu söylemektedirler. Bagozzi ve Yi (1988) ise tüm analizler için CRC güvenilirlik katsayısını 0,60 ve üzerinde bir değer olması gerektiğini ssavunmktadır. Bu görüşler doğrultusunda algılanan çevresel olumsuzluğa ilişkin değişken için ortaya konulan 0,67 güvenilirlik katsayısı, gerçekleştirilmiş olan analizler bakımından bir problem oluşturmamaktadır. $\mathrm{Bu}$ bulgular çerçevesinde, çalışma ile toplanan verilerin de bunlara göre elde edilecek değişkenlerin de istatistiksel anlamda geçerli olduklarını söylemek mümkündür. 


\subsection{Araştırmanın Bulguları ve Değerlendirilmesi}

Anket çalışması sonucunda geri dönüşü sağlanan anketlerden elde edilen veriler tablo haline getirilmiş, sonuçlar değerlendirilmiş ve aşağıdaki bulgular elde edilmiştir.

Tablo 2.3a. Performansı Etkileyen Değişkenlerin Ortalama Değerleri

\begin{tabular}{|l|c|c|}
\hline & Ortalama & Standart Sapma \\
\hline Algılanan Çevresel Olumsuzluk & $\mathbf{4 , 0 0}$ & $\mathbf{0 , 6 9}$ \\
\hline Algılanan Kurumsal Sosyal Sorumluluk & $\mathbf{4 , 1 1}$ & $\mathbf{0 , 4 4}$ \\
\hline \multicolumn{1}{|c|}{ Toplum, gelecek nesiller, doğal çevre ve STK'lar $^{*}$} & 3,87 & 0,58 \\
\hline Çalışanlar $^{*}$ & 3,99 & 0,56 \\
\hline Tüketiciler/Gönüllüler $^{*}$ & 4,53 & 0,55 \\
\hline Yasal Sorumluluk* $^{*}$ & 4,73 & 0,45 \\
\hline Algılanan Pazar Dinamizmi & $\mathbf{3 , 7 9}$ & $\mathbf{0 , 8 6}$ \\
\hline Algılanan İşletme Kültürür & $\mathbf{3 , 9 5}$ & $\mathbf{0 , 6 5}$ \\
\hline Algılanan Üretim Performansı & $\mathbf{4 , 2 1}$ & $\mathbf{0 , 6 5}$ \\
\hline Algılanan Yenilikçilik & $\mathbf{4 , 0 1}$ & $\mathbf{0 , 6 5}$ \\
\hline Algılanan Müşteri Odaklılık & $\mathbf{3 , 7 7}$ & $\mathbf{0 , 6 7}$ \\
\hline
\end{tabular}

Tablo 2.3b. Performans Prizması Alt Boyutlarının Ortalama Değerleri

\begin{tabular}{|l|c|c|}
\hline & Ortalama & Standart Sapma \\
\hline Algılanan Paydaş Memnuniyeti Boyutu & $\mathbf{3 , 3 9}$ & $\mathbf{0 , 9 1}$ \\
\hline Algılanan Stratejiler Boyutu & $\mathbf{3 , 7 5}$ & $\mathbf{0 , 9 0}$ \\
\hline Algılanan Süreç (İşlemler) Boyutu & $\mathbf{4 , 1 5}$ & $\mathbf{0 , 8 4}$ \\
\hline Algılanan Yetkinlikler Boyutu & $\mathbf{4 , 0 6}$ & $\mathbf{0 , 8 0}$ \\
\hline Algılanan Paydaş Katkısı Boyutu & $\mathbf{3 , 5 6}$ & $\mathbf{0 , 9 8}$ \\
\hline
\end{tabular}

\subsubsection{Korelasyon Matrisi}

Tablo 2.4. Performans Prizmasının Alt Boyutları ve Performansı Etkileyen Faktörler ile İlgili Korelasyon Matrisi görülmektedir. 
Tablo 2.4. Performans Prizmasının Alt Boyutları ve Performansı Etkileyen Faktörler ile İlgili Korelasyon Matrisi

\begin{tabular}{|c|c|c|c|c|c|c|c|c|c|c|c|c|}
\hline & 1 & 2 & 3 & 4 & 5 & 6 & 7 & 8 & 9 & 10 & 11 & 12 \\
\hline $\begin{array}{l}\text { 1. Algılanan Paydaş } \\
\text { Memnuniyeti Boyutu }\end{array}$ & 1 & & & & & & & & & & & \\
\hline 2. Algılanan Strateji Boyutu & $.773^{* *}$ & 1 & & & & & & & & & & \\
\hline $\begin{array}{l}\text { 3.Algılanan Süreç (İşlemler) } \\
\text { Boyutu }\end{array}$ & $.572^{* *}$ & $.697^{* *}$ & 1 & & & & & & & & & \\
\hline $\begin{array}{l}\text { 4. Algilanan Yetkinlik } \\
\text { Boyutu }\end{array}$ & $.586^{* *}$ & $.661^{* *}$ & $.821^{* *}$ & 1 & & & & & & & & \\
\hline $\begin{array}{l}\text { 5.Algılanan Paydaş Katkısı } \\
\text { Boyutu }\end{array}$ & $.700^{* *}$ & $.681^{* *}$ & $.594^{* *}$ & $.695^{* *}$ & 1 & & & & & & & \\
\hline $\begin{array}{l}\text { 6. Algılanan Çevresel } \\
\text { Olumsuzluk }\end{array}$ & .129 & -.030 & .086 & .078 & .022 & 1 & & & & & & \\
\hline $\begin{array}{l}\text { 7. Algilanan Kurumsal Sosyal } \\
\text { Sorumluluk }\end{array}$ & $.476^{* *}$ & $.417^{* *}$ & $.376^{* *}$ & $.405^{* *}$ & $.401^{* *}$ & $.170^{*}$ & 1 & & & & & \\
\hline $\begin{array}{l}\text { 8. Algılanan Pazar } \\
\text { Dinamizmi }\end{array}$ & .097 & .072 & .016 & .076 & .046 & $.227^{* *}$ & $.209^{* *}$ & 1 & & & & \\
\hline 9. Algılanan İşletme Kültürü & $.472^{* *}$ & $.491^{* *}$ & $.361^{* *}$ & $.304^{* *}$ & $.333^{* *}$ & .012 & $.447^{* *}$ & .074 & 1 & & & \\
\hline $\begin{array}{l}\text { 10. Algılanan Üretim } \\
\text { Performans1 }\end{array}$ & $.320^{* * *}$ & $.307^{* *}$ & $.305^{* *}$ & $.322^{* *}$ & $.304^{* *}$ & .124 & $.428^{* *}$ & $.201^{* *}$ & $.277^{* *}$ & 1 & & \\
\hline 11. Algılanan Yenilikçilik & $.469^{* *}$ & $.390^{* *}$ & $.423^{* *}$ & $.437^{* *}$ & $.371^{* *}$ & $.321^{* *}$ & $.613^{* *}$ & $.261^{* *}$ & $.478^{* *}$ & $.508^{* *}$ & 1 & \\
\hline $\begin{array}{l}\text { 12. Algılanan Müşteri } \\
\text { Odaklılık }\end{array}$ & $.550^{* *}$ & $.366^{* *}$ & $.267^{* *}$ & $.355^{* *}$ & $.386^{* *}$ & $.294^{* *}$ & $.604^{* *}$ & $.159^{*}$ & $.406^{* *}$ & $.301^{* *}$ & $.631^{* * *}$ & 1 \\
\hline
\end{tabular}

$$
\text { ** } \mathrm{p}<0,01 ; * \mathrm{p}<0,0
$$




\subsection{Araştırma Hipotezleri ve Test Edilmesi}

Araştırma kapsamındaki belirlenen temel değişkenler olan performans prizmasını etkileyen diğer değişkenler ile performans prizması modelinin alt boyutlarını kapsayan bir model kurulmuş ve modelde belirlenen değişkenlerle ilgili hipotezler belirlenmiştir.

\subsubsection{Model ve Hipotezleri}

Araştırmanın modeli kapsamında yedi ana hipotez ve her bir ana hipoteze ait beş alt hipotez bulunmaktadır.

Hipotez 1: Algılanan Çevresel Olumsuzluğun algılanan performans prizması boyutları üzerinde pozitif ve anlaml etkisi vardır.

Hipotez 2: Algılanan Kurumsal Sosyal Sorumluluğun algılanan performans prizması boyutları üzerinde pozitif ve anlamlı etkisi vardir.

Hipotez 3: Algllanan Pazar Dinamizminin algllanan performans prizması boyutları üzerinde pozitif ve anlamlı etkisi vardır.

Hipotez 4: AlgllananIşletme Kültürünün algllanan performans prizması boyutları üzerinde pozitif ve anlamlı etkisi vardır.

Hipotez 5: AlgllananÜretim Performansının algılanan performans prizması boyutları üzerinde pozitif ve anlaml etkisi vardır.

Hipotez 6: AlgılananYenilikçiliğin algılanan performans prizması boyutları üzerinde pozitif ve anlamlı etkisi vardir.

Hipotez 7: AlgılananMüşteri Odaklılı̆̆ın algılanan performans prizması boyutları üzerinde pozitif ve anlamlı etkisi vardır.

\subsubsection{Model'in Hipotez Testleri}

Hipotezler neticesinde değişkenler arasında bir ilişkinin varlığını ve etkisini ölçmek amacıyla hazır bir istatistik paket programında regrasyon analizi yapılmıştır. Yapılan regrasyon analizi neticesinde algılanan paydaş memnuniyeti boyutu ile diğer yedideğişken arasındaki bağıntının varlığı, varlığın etkisi ve ilişkinin güçlülük derecesi tespit edilmeye çalışılmıştır.

Aşağıdaki tablolarda yapilan regrasyon analizlerinin sonuçlarına yer verilmiştir. Algılananperformans prizması boyutlarından biri olan algılanan paydaş memnuniyeti boyutu bağımlı; diğer değişkenler ise (algılanan çevresel olumsuzluk, algılanan kurumsal sosyal sorumluluk, algılanan pazar dinamizmi, algılanan işletme kültürü, algılanan üretim performansı, algılanan yenilikçilik, algılanan müşteri odaklılık) bağımsız değişken olarak kabul edilmiştir. Bu regresyonlarda yer alan her bir değişken, kendisini meydana getiren soruların her bir gözlem için toplamlarının ortalaması alınarak (summatedavaragescore) analize dahil edilmiştir.

Tablo 2.5. Algılanan Müşteri Odaklılık ve Algılanan İşletme KültürününAlgılanan Paydaş Memnuniyeti Boyutu Üzerindeki Etkisi- Model Özeti

\begin{tabular}{|c|c|c|c|c|c|}
\hline Değişkenler & $\mathbf{R}$ & $\mathbf{R}^{2}$ & Düzeltilmiş $\mathbf{R}^{2}$ & $\mathbf{F}$ & Sig.(p) \\
\hline $\begin{array}{c}\text { Algılanan Müşteri Odaklılık, } \\
\text { Algılanan İşletme Kültürü }\end{array}$ & 0,614 & 0,377 & 0,369 & 53,444 & 0,000 \\
\hline
\end{tabular}

Bağımlı değişken: Algılanan Paydaş MemnuniyetiBoyutu

Tabloya göre algılanan müşteri odakl1lık ve algılanan işletme kültürü değişkenlerinin performans prizması boyutlarından algılanan paydaş memnuniyeti boyutu üzerinde bir etkisinin olduğu ortaya çıkmaktadır. Performansı etkileyen bağımsız değişkenlerden algılanan müşteri odaklılık ve algılanan işletme kültürü değişkenlerinin algılanan paydaş memnuniyeti boyutunu açıklama derecesi (düzeltilmiş R2 katsayısı) 0,369 olarak bulunmuştur. $\mathrm{Bu}$ değer, algılanan paydaş memnuniyeti boyutunun 0,369'unun bağımsız değişkenler olan algılanan müşteri odaklılık $(p<0,05)$ ve algılanan işletme kültürü $(p<0,05)$ ile açıklanabileceğini ifade etmektedir. Bu durumda 0,631’i burada öngörülmeyen değişkenlerce açılanmaktadır. 
Tablo 2.6. Algılananİşletme Kültürü ve Algılanan Kurumsal Sosyal Sorumluluğun Algılanan Stratejiler Boyutu Üzerindeki Etkisi- Model Özeti

\begin{tabular}{|c|c|c|c|c|c|}
\hline Değişkenler & $\mathbf{R}$ & $\mathbf{R}^{\mathbf{2}}$ & Düzeltilmiş $\mathbf{R}^{\mathbf{2}}$ & F & Sig.(p) \\
\hline $\begin{array}{c}\text { Algılanan İşletme Kültürü, } \\
\text { Algılanan Kurumsal Sosyal } \\
\text { Sorumluluk }\end{array}$ & 0,538 & 0,290 & 0,282 & 36,140 & 0,000 \\
\hline
\end{tabular}

Bağımlı değişken: Algılanan Stratejiler Boyutu

Tabloya göre bağımsız değişken olan algılanan kurumsal sosyal sorumluluk ve algılanan işletme kültürü değişkenlerinin performans prizması boyutlarından algılanan stratejiler boyutu üzerinde bir etkisinin olduğu ortaya çıkmaktadır. $\mathrm{Bu}$ değişkenlerin algılanan stratejiler boyutunu açıklama derecesi (düzeltilmiş R2 katsayısı) 0,282 olarak bulunmuştur. Bu değer, algılanan stratejiler boyutunun 0,282'sinin bağımsız değişkenler olan algılanan işletme kültürü $(p<0,05)$ ve algılanan kurumsal sosyal sorumluluk $(p<0,05)$ ile açıklanabileceğini ifade etmektedir. Bu durumda 0,718 'i burada öngörülmeyen değişkenlerce açıklanmaktadır.

Tablo 2.7. Algılanan Yenilikçilik ve Algılanan İşletme Kültürünün Algılanan Süreçler (İşlemler) Boyutu Üzerindeki Etkisi-Model Özeti

\begin{tabular}{|c|c|c|c|c|c|}
\hline Değişkenler & $\mathbf{R}$ & $\mathbf{R}^{\mathbf{2}}$ & Düzeltilmiş $\mathbf{R}^{\mathbf{2}}$ & $\mathbf{F}$ & Sig.(p) \\
\hline $\begin{array}{c}\text { AlgılananYenilikçilik, } \\
\text { Algılanan İşletme Kültürü }\end{array}$ & 0,460 & 0,211 & 0,203 & 23,731 & 0,000 \\
\hline
\end{tabular}

Bağımlı değişken: Algılanan Süreçler (İşlemler) Boyutu

Tabloya göre algılanan yenilikçilik ve algılanan işletme kültürü değişkenlerinin performans prizması boyutlarından algılanan süreçler (işlemler) boyutu üzerinde bir etkisinin olduğu ortaya çıkmaktadır. Performansı etkileyen bağımsız değişkenlerden algılanan yenilikçilik ve algılanan işletme kültürü değişkenlerinin algılanan süreçler (işlemler) boyutunu açıklama derecesi (düzeltilmiş R2 katsayısı) 0,203 olarak bulunmuştur. Bu değer, algılanan süreçler (işlemler) boyutunun 0,203'ünün bağımsız değişkenler olan algılanan yenilikçilik $(p<0,05)$ ve algılanan işletme kültürü $(p<0,05)$ ile açıklanabileceğini ifade etmektedir. Bu durumda 0,797'si burada öngörülmeyen değişkenlerce açıklanmaktadır.

Tablo 2.8. Algılanan Yenilikçilik ve Algılanan Kurumsal Sosyal Sorumluluğun Algılanan Yetkinlikler Boyutu Üzerindeki Etkisi-Model Özeti

\begin{tabular}{|c|c|c|c|c|c|}
\hline Değişkenler & $\mathbf{R}$ & $\mathbf{R}^{\mathbf{2}}$ & $\begin{array}{c}\text { Düzeltilmiş } \\
\mathbf{R}^{\mathbf{2}}\end{array}$ & $\mathbf{F}$ & Sig.(p) \\
\hline $\begin{array}{c}\text { Algılanan Yenilikçilik, } \\
\text { Algılanan Kurumsal Sosyal } \\
\text { Sorumluluk }\end{array}$ & 0,470 & 0,221 & 0,213 & 25,161 & 0,000 \\
\hline
\end{tabular}

Bağımlı değişken: Algılanan Yetkinlikler Boyutu

Tabloya göre algılanan yenilikçilik ve algılanan kurumsal sosyal sorumluluk değişkenlerinin performans prizması boyutlarından algılanan yetkinlikler boyutu üzerinde bir etkisinin olduğu ortaya çıkmaktadır. Bu değişkenlerin algılanan yetkinlikler boyutunu açıklama derecesi (düzeltilmiş R2 katsayıs1) 0,213 olarak bulunmuştur. $\mathrm{Bu}$ değer, algılanan yetkinlikler boyutunun 0,213'ünün bağımsız değişkenler olan algılanan yenilikçilik $(\mathrm{p}<0,05)$ ve algılanan kurumsal sosyal sorumluluk $(\mathrm{p}<0,05)$ ile açıklanabileceğini ifade etmektedir. $\mathrm{Bu}$ durumda 0,787'si burada öngörülmeyen değişkenlerce açıklanmaktadır. 
Tablo 2.9. Algılanan Kurumsal Sosyal Sorumluluk, Algılanan Müşteri Odaklıık ve Algılanan İşletme Kültürünün Algılanan Paydaş Katkısı Boyutu Üzerindeki Etkisi- Model Özeti

\begin{tabular}{|c|c|c|c|c|c|}
\hline Değişkenler & $\mathbf{R}$ & $\mathbf{R}^{\mathbf{2}}$ & Düzeltilmiş $\mathbf{R}^{\mathbf{2}}$ & $\mathbf{F}$ & Sig.(p) \\
\hline $\begin{array}{c}\text { Algılanan Kurumsal Sosyal } \\
\text { Sorumluluk, } \\
\begin{array}{c}\text { Algılanan Müşteri Odaklılık, } \\
\text { Algılanan İ̧̧letme Kültürü }\end{array}\end{array}$ & 0,462 & 0,213 & 0,200 & 15,877 & 0,000 \\
\hline
\end{tabular}

Bağımlı değişken: Algılanan Paydaş Katkısı Boyutu

Tabloya göre bağımsız değişken olan algılanan kurumsal sosyal sorumluluk, algılanan müşteri odaklılık ve algılanan işletme kültürü değişkenlerinin performans prizması boyutlarından algılanan paydaş katkısı boyutu üzerinde bir etkisinin olduğu ortaya çıkmaktadır. Algılanan kurumsal sosyal sorumluluk, algılanan müşteri odaklılık ve algılanan işletme kültürü değişkenlerinin algılanan paydaş katkısı boyutunu açıklama derecesi (düzeltilmiş R2 katsayıs1) 0,200 olarak bulunmuştur. Bu değer, algılanan paydaş katkısı boyutunun 0,200'ünün bağımsız değişkenler olan algılanan kurumsal sosyal sorumluluk $(\mathrm{p}<0,05)$, algılanan müşteri odaklılık $(p<0,05)$ ve algılanan işletme kültürü $(p<0,05)$ ile açıklanabileceğini ifade etmektedir. Bu durumda 0,800'ü burada öngörülmeyen değişkenlerce açıklanmaktadır.

Tablo 2.10. Algılanan Yenilikçilik, Algılanan İşletme Kültürü ve Algılanan Kurumsal Sosyal Sorumluluğun Algılanan Performans Prizması Üzerindeki Etkisi-Model Özeti

\begin{tabular}{|c|c|c|c|c|c|}
\hline Değişkenler & $\mathbf{R}$ & $\mathbf{R}^{\mathbf{2}}$ & Düzeltilmiş $\mathbf{R}^{\mathbf{2}}$ & $\mathbf{F}$ & Sig.(p) \\
\hline $\begin{array}{c}\text { AlgılananYenilikçilik, } \\
\text { Algılananİşletme Kültürü, } \\
\begin{array}{c}\text { AlgılananKurumsal Sosyal } \\
\text { Sorumluluk }\end{array}\end{array}$ & 0,577 & 0,333 & 0,322 & 29,322 & 0,000 \\
\hline
\end{tabular}

Bağımlı değişken: Algılanan Performans Prizması

Tabloya göre algılanan yenilikçilik, algılanan işletme kültürü ve algılanan kurumsal sosyal sorumluluk değişkenlerinin algılanan performans prizması üzerinde bir etkisinin olduğu ortaya çıkmaktadır. $\mathrm{Bu}$ değişkenlerin algılanan performans prizmasını açıklama derecesi (düzeltilmiş R2 katsayıs1) 0,322 olarak bulunmuştur. $\mathrm{Bu}$ değer, algılanan performans prizmasının 0,322'sinin bağımsız değişkenler olan algılanan yenilikçilik $(p<0,05)$, algılanan işletme kültürü $(p<0,05)$ ve algılanan kurumsal sosyal sorumluluk $(p<0,05)$ ile açıklanabileceğini ifade etmektedir. Bu durumda 0,678'i burada öngörülmeyen değişkenlerce açıklanmaktadır.

Analizler sonucunda çalışmada ileri sürülen Model'in hipotezlerinin reddedilebilir/reddedilemez durumları Tablo2.11'de gösterilmektedir.

Tablo 2.11. Model'inHipotezlerine İlişkin Reddedilebilir/Reddedilemez Durumu

\begin{tabular}{|l|c|}
\hline \multicolumn{1}{|c|}{ İLERİ SÜRÜLEN HİPOTEZLER } & $\begin{array}{c}\text { REDDEDİLEBİLİR } \\
\text { /REDDELİLEMEZ }\end{array}$ \\
\hline $\begin{array}{l}\text { Hipotez 1: Algılanan Çevresel Olumsuzluğun algılanan performans prizması } \\
\text { boyutları üzerinde pozitif ve anlamlı etkisi vardır. }\end{array}$ & Reddedilebilir \\
\hline $\begin{array}{l}\text { Hipotez 2: Algılanan Kurumsal Sosyal Sorumluluğun algılanan performans } \\
\text { prizması boyutları üzerinde pozitif ve anlamlı etkisi vardır. }\end{array}$ & Reddelilemez \\
\hline $\begin{array}{l}\text { Hipotez 3: Algılanan Pazar Dinamizminin algılanan performans prizması } \\
\text { boyutları üzerinde pozitif ve anlamlı yönlü etkisi vardır. }\end{array}$ & Reddedilebilir \\
\hline $\begin{array}{l}\text { Hipotez 4: Algılanan İşletme Kültürünün algılanan performans prizması } \\
\text { boyutları üzerinde pozitif ve anlamlı etkisi vardır. }\end{array}$ & Reddelilemez \\
\hline
\end{tabular}




\begin{tabular}{|l|c|}
\hline $\begin{array}{l}\text { Hipotez 5: Algılanan Üretim performansının algılanan performans prizması } \\
\text { boyutları üzerinde pozitif ve anlamlı etkisi vardır. }\end{array}$ & Reddedilebilir \\
\hline $\begin{array}{l}\text { Hipotez 6: Algılanan Yenilikçiliğin algılanan performans prizması boyutları } \\
\text { üzerinde pozitif ve anlamlı etkisi vardır. }\end{array}$ & Reddelilemez \\
\hline $\begin{array}{l}\text { Hipotez 7: Algılanan Müşteri Odaklılığın algılanan performans prizması } \\
\text { boyutları üzerinde pozitif ve anlamlı etkisi vardır. }\end{array}$ & Reddedilebilir \\
\hline
\end{tabular}

Standardize edilmiş $\beta$ katsayıları incelendiğinde performans prizmasını en güçlü olarak pozitif yönde birinci sırada algılanan işletme kültürünün etkilediği görülmektedir (Standardize edilmiş $\beta$ katsayısı $\beta=0,245$ ). İkinci sırada algılanan kurumsal sosyal sorumluluk (Standardize edilmiş $\beta$ katsayısı $\beta=0,237$ ) ve son olarak da yine pozitif yönde algılanan yenilikçilik değişkeni etkilemektedir (Standardize edilmiş $\beta$ katsayısı $\beta=$ $0,221)$.

\section{SONUÇ}

Dünyadaki küreselleşme ile hızlı bir değişim sürecine giren işletmelerin alacakları kararların sağlıklı olması için performanslarını ölçmeleri ve buna göre hareket etmeleri önemli hale gelmiştir. Performans ölçümünü uygulayan işletmeler kendilerine özel misyonları ve vizyonları yönünde hedef belirlerler, sonrasında ise doğru stratejik yaklaşımları uygulayarak bu hedeflere ulaşabilirler. İlgili süreçte başarının elde edilebilmesi için, işletmelerin eksik olduğu yönlerini tespit ederek geliştirmeleri ve üstünlüklerini gösteren taraflarını da en doğru bir biçimde kullanmaları gerekmektedir.

Performans ölçümü yoluyla; işletme sahipleri, yönetimde bulunanların, yatırımcı kimliğine sahip olanların ve kredi veren taraflar gibi işletmenin içinde ve dışında yer alan çeşitli grupların işletmeye yönelik verdikleri kararlar etkilemektedir. Bu çerçevede; kurumsallığını ortaya koyabilen işletmelerden büyük bir kısmı; sistematik bir biçimde, kısa süreliğine ya da belirlenmiş bir amaç doğrultusunda performans ölçümünü gerçekleştirmektedir. Performans ölçümü yapılarak; işletmenin hangi düzeyde başarılı olduğunun tespit edilmesi, gelişim sağlanabilecek alanların ortaya konulması, verimsizlik sebeplerinin anlaşılması ve işletmeyi başarılı olmaya taşıyacak kararların alınmasında yardımcı olmaktadır.

Geçmişten bugüne performans ölçüm sistemlerinin gelişimi incelendiğinde finansal yapıya ilişkin göstergeleri bulunan geleneksel yaklaşımlı ölçüm sistemleri, yerlerini çok boyutlu ölçüm sistemlerine bırakmaktadır. Çünkü geleneksel yaklaşımlı modeller, geçmişe dönük bir görüş açısı içermekte, gelecekteki işletme performansı için fikir vermemekte ve nedenselliğe yönelik ilişkiler hakkında verdiği bilgi yetersiz kalmaktadır. Ayrıca geleneksel modeller bütünleşik ve esnek bir yapı sergilememekte, devamlı olarak iyileştirmeler yapılması mantığıyla çelişmekte ve müşterilerin gereksinim hissettiklerini gözardı etmektedir. Halbuki işletme performansı çok boyutlu bir yapıdan oluşmaktadır. Bu bakımdan işletmelerin tüm boyutlarıyla (kalite, müşteriler, kârlılık, esneklik, yenilik, insan kaynakları gibi) değerlendirilmesini sağlayacak çok boyutlu performans değerleme modellerine ihtiyaç bulunmaktadır.

$\mathrm{Bu}$ çalışmada işletmelerde performans ölçülmesi ve gerekliliğine değinilmiş olup, uygulamada kullanılan performans ölçüm sistemlerinden bahsedilerek finansal içerikli olan ve olmayan çeşitli ölçümlerin birlikte kullanılabildiği birçok boyutu bulunan, bütünleştirme özelliğiyle dikkat çeken, performans ölçümünün gerçekleştirildiği modellerden “Performans Prizması" ölçüm modeli üzerine bir araştırma yapılmıştır.

Model teorik kapsamıyla; Paydaş Memnuniyetini, Stratejileri, Süreçleri (işlemleri), Yetkinlikleri ve Paydaş Katkısını içererek beş ayrı boyuttan meydana gelmektedir. Bu boyutlarla; işletmelerin misyonları ve stratejileri geniş içerikte performans ölçütlerinden oluşan bir set haline dönüşmekte, finansman yapılı performans ölçütlerinin yanında finansman yapılı olmayan performans ölçütleri de aralarında denge sağlanacak bir biçimde kullanılabilmekte ve işletmeye ait maddi varlıklar ile beraber maddi olmayan varlıkların değerleri de göz önünde bulundurulmaktadır. Söz konusu yöntemin başarısında; bir yandan paydaş ihtiyaçlarının diğer yandan da işletme açısından bunların gerçekleştirilmesine yönelik ihtiyaçların dikkate alınması etkili olmaktadır

Model, birbirinden farklı paydaşlara yönelik olarak çok yönlü bir bakış açısına işlemektedir. Çok sayıda performans değerlemesine ilişkin yaklaşımların tersi olarak; değerleme amacıyla başlangıçta; stratejiye değil, paydaşlara yer vermektedir. Modeldeki en kuvvetli yön, ölçütlerin seçilmesi sürecinin öncesinde, işletme tarafindan var olan stratejisinin sorgulanmasıdır. Öncelikle paydaşların ihtiyaç ve isteklerini gözönüne almakta, daha sonra stratejileri düzenlemektedir. Model, paydaşların işletmeden isteklerini göz önünde tutarak daha ileri aşamalara yönelik stratejiler oluşturulması, süreçlerin (işlemlerin) ve kapasitenin artışı oluşumunu sağlamaktadır. 
Bu çalışmada çok boyutlu performans ölçüm modellerinden olan performans prizması ölçüm modeli ile ilgili bir uygulama örneğine yer verilmiştir. Araştırmanın ana kütlesini Kayseri Organize Sanayi Bölgesi dahilinde faaliyetlerini gerçekleştiren küçük ve orta ölçekli işletmeler (KOBİ) oluşturmaktadır. Organize Sanayi Bölge Müdürlüğü'ndan alınan verilere göre araştırma evrenine dahil olabilecek çeşitli sektörlerde faaliyet gösteren 593 işletme bulunmaktadır. Bunlardan 180 işletmeye ulaşılmış ve anket yapılmıştır.

Verilerin toplanması için geçerlilik ve güvenilirlik bakımından önceden gerçekleştirilmiş çalışmalar üzerinde test edilmiş olan ölçeklerden faydalanılmıştır. Araştırma kapsamında belirlenen temel değişkenler olan performans prizmasını etkileyen değişkenler ile performans prizması modelinin alt boyutlarını kapsayan bir model kurulmuş ve modelde belirlenen değişkenlerle ilgili hipotezler test edilmiştir.

Araştırmanın modeli kapsamında "çeşitli değişkenlerin algılanan performans prizması boyutları üzerine etkisi" araştırılmıştır. Modelde yedi ana hipotez ve her bir ana hipoteze ait beş alt hipotez bulunmaktadır. Hipotezler neticesinde Algllanan Paydas Memnuniyeti Boyutunu; algilanan işletme kültürü $(\beta=0,297)$ ve algılanan müşteri odaklık $(\beta=0,430)$, Algilanan Stratejiler Boyutunu; alg1lanan kurumsal sosyal sorumluluk $(\beta=0,246)$ ve algılanan işletme kültürü $(\beta=0,381)$ ve Algllanan Süreçler (ISslemler) Boyutunu ise algilanan işletme kültürü $(\beta=0,206)$ ve algılanan yenilikçiliğin $(\beta=0,325)$ pozitif yönde etkilediği görülmektedir.

Prizmanın diğer bir boyutu olan Algilanan Yetkinlikler Boyutunu; algılanan kurumsal sosyal sorumluluk $(\beta=0,220)$ ve algılanan yenilikçilik $(\beta=0,302)$ ve son olarak da Algılanan Paydaş Katkısı Boyutunu; algılanan kurumsal sosyal sorumluluk $(\beta=0,214)$, algılanan işletme kültürü $(\beta=0,159)$ ve algılanan müssteri odaklılığın $(\beta=0,192)$ yine pozitif yönde etkilediği görülmektedir.

Genel olarak algılanan kurumsal sosyal sorumluluk $(\beta=0,237)$, algılanan işletme kültürü $(\beta=0,245)$ vealgılanan yenilikçiliğin $(\beta=0,221)$ Algılanan Performans Prizmasını pozitif yönde etkilediği görülmüştür. Yapılan analiz neticesinde modelde de görüldüğü üzere algılanan çevresel olumsuzluk, algılanan pazar dinamizmi ve algılanan üretim performansı değişkenlerinin algılanan performans prizması ve boyutları üzerinde hiçbir etkileri bulunmamaktadır. Modelin sonucu özetle şöyledir. 


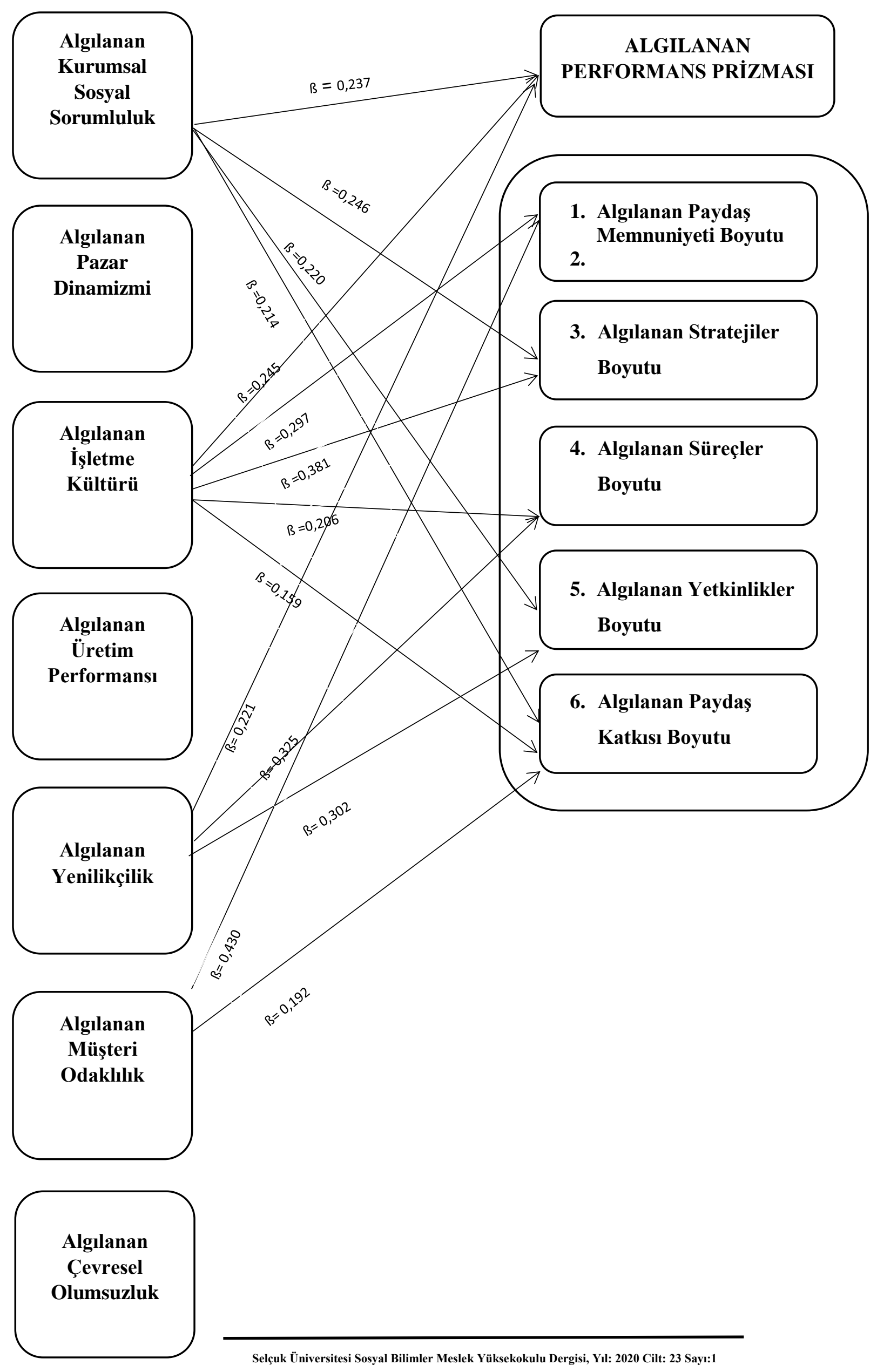


Performans ölçümü yöntemleri söz konusu olduğunda çok boyutu kapsayan bir bakış açısı destekli, işletmenin her bakımdan değerlendirilmesini gerçekleştiren bu modele ilişkin temel boyutların ortaya konulmasıyla beraber sağlıklı bir biçimde kullanılması sonucunda, işletmenin başarı grafiğine pozitif katkısı olabileceği açıktır.

Bütün performans ölçüm modelleri dikkate alındığında, işletme başarısı için katkı sağlaması amacıyla; model uygulayıcılarının istekli ve kararlı çalışmalarının ön koşul olduğunu unutmamak gerekmektedir. Yönetim tarafından alınan kararın işletmede çalışanlar ve paydaşlar tarafından hayata geçirilmesi önemli diğer bir noktayı oluşturmaktadır. Bu bağlamda mevcut sistemlerin çalışanlara ve paydaşlara yönelik etkilerinin daha geniş kapsamlı araştırılması gerekmektedir. Bununla birlikte performans artışı sonucu oluşacak getirilerin işletmede bütün olarak paylaşılması da sistemin devamlılı̆̆ı anlamında yarar sağlayacaktır.

İşletmelerin faaliyetleri sonucunda değer yaratması faaliyetlerini sürdürebilmeleri açısından büyük önem taşımaktadır. Bir işletmenin performansı, belli bir zaman diliminde elde edilen çıktı ya da çalışmanın sonucudur. Buna göre işletmelerin, performanslarınındeğerlendirilerek elde edilen sonuçların nedenlerinin araştırılması ve bunlarıniyileştirilmesi, performans artısına sebep olacaktır.

Performans Prizması, doğruluğu açık ve öneme sahip ölçümlerin bir araya toplanması hedefi doğrultusunda oluşturulan, işletmelerin kârlılık elde etmelerini sağlayacak öneme sahip konuların dikkate alınmasıyla işletmenin tümüne uygulanmaya çalışılan gelişmiş ve geniş kapsamı olan bir ölçüm sistemidir. Model, kâr amaçlı olan ve olmayan tümüretim ve hizmet işletmelerinde uygulanabilir ve işletmenin etkili bir şekilde yönetilerek, sağlıklı bir şekilde değerlendirilmesine yardımcı olabilir.

$\mathrm{Bu}$ çalışma, Kayseri Organize Sanayi Bölgesi'nde faaliyetlerini yürütmekte olan küçük ve orta ölçekli işletmeler üzerinde gerçekleştirilmiştir. Araştırmanın gerçekleştirilmesi sırasında uygulamanın geniş bir zamanı alması, işletmelerdeki üst yönetimlerin katılmaları gereği, işletmelerdeki yöneticilerin akademik içerikli çalışmaları desteklemekten uzak bir tavır sergilemeleri ve bu modelin henüz ülkemizde yeterli düzeyde bilinmeyen bir uygulama olması gibi bazı zorluklar ve kısıtlar ile karşı karşıya kalınmıştır.

Özellikle verimlilik ve etkinlik düzeylerinin artırılması için bir araç olarak görülen performans ölçümü ve değerlendirmesi noktalarında, karşılaşılan problemlere çözümler üretebilmek amaçlarına hizmet edecek şekilde, işletmeler tarafından performans yönetimi uygulamalarının çok iyi bir biçimde ortaya konulması gerekmektedir. İşletmeler bu süreçte performans geliştirilmesine yönelik bir plan geliştirmeli, amaçlarını tespit etmeli ve işletmenin mevcut performansını değerlendirip, ölçmelidir. Performans konusunda ortaya çıkan mevcut sorunlar belirlenmeli, var olan performans ve ulaşılması hedeflenen performans düzeyleri arasında bulunan, performansa ilişkin açık miktarı belirlenmeli ve giderilmesi için performans yönetimine yönelik yeni yöntem ve teknikler uygulanmalıdır. Bu doğrultuda performansın sürekli olarak geliştirilmesi sağlanılmalıdır.

İşletmeler tarafından performans ölçüm modellerindeki değişim sürecinin dikkatlice incelenmesi, kullanılabilecekleri performans ölçümü modelinin sorgulanarak; gerçekte işletme için belirlenen amaçlara ve var olan verilere yönelik ölçümlemeye uygunluk düzeyi profesyonel bir bakış açısıyla değerlendirilmesi ve uygulanan modellerde esneklikler sağlanması, kurumsal sosyal sorumluluğun, soyut nitelikli varlıkların ölçümlenmesi, rekabet ve kıyaslamayı önemsemeleri gerekmektedir.

Araştırmanın genelleştirilebilmesi için bu çalışmanın farklı sektör ve büyüklükteki işletmeler üzerinde de yapılması bundan sonraki yapılacak çalışmalara önerilebilir. Bu çalışmadan elde edilen sonuçlarla, başka performans değerleme modelleri ile elde edilecek sonuçlar karşılaştırılabilir. Böylece daha sağlıklı değerlendirmeler yapılabilir.

Son olarak çalışmanın literatüre ve araştırmacılara yapacağı bazı katkıları şöyle sıralamak mümkündür. Modelinin genel olarak literatürde ve ülkemizde imalat işletmelerinde uygulanmadığı, yurt dişında ise daha çok hizmet işletmelerine yönelik uygulamalar yapıldığı görülmektedir. Bu nedenle çalışmanın teorik ve pratik bakımlardan, üretim ve hizmet alanında faaliyetler gerçekleştiren işletmeler tarafindan uygulanabilir bir rehber olacağı düşünülmektedir. Ayrıca araştırmacıların bu konuda yapacakları çalışmalara da bazı yönlerden temel teşkil edeceği beklenmektedir. 


\section{KAYNAKÇA}

Adams, C. and Neely, Andy. (2000). “The Performance Prism to Boost M\&A Success”. Measuring Business Excellence, 19-23.

Ağca, Veysel. (2005). “İç Girişimcilik Yapısı ve Firma Performansına Etkileri: Denizli Tekstil Sektöründeki Firmalarda Bir Araştırma”. Doktora Tezi, Afyon Kocatepe Üniversitesi Sosyal Bilimler Enstitüsü, Afyon.

Ağca, Veysel. (2009). "Türk İmalat İşletmelerinde Çok Boyutlu Performans Değerleme (PD) Modellerine Dayalı Performans Göstergelerinin Kullanılabilirliğii”. Dumlupınar Üniversitesi Sosyal Bilimler Dergisi, 23, 51-66.

Akal, Zuhal. (Eylül 2005). İşletmelerde Performans Ölçüm ve Denetimi: Çok Yönlü Performans Göstergeleri (6. Baskı). Milli Prodüktivite Merkezi Yayınları No: 473. Ankara: Bizim Büro Basın Yayın Dağıtım.

Baş, İ. Melih. ve Artar, Ayhan. (1991). İşletmelerde Verimlilik Denetimi: Ölçme ve Değerlendirme Modelleri. Ankara: Milli Prodüktivite Merkezi Yayınları No: 435.

Bagozzi, Richard. P. and Yi, Yauyae. (1988). “On the Evaluation of Structural Equation Model”. Journal of the Academy of Marketing Science, 16, 74-94.

Coşkun, Ali. (Temmuz 2006). “Büyük Sanayi İşletmelerinde Kurumsal Performans Ölçüm ve Yönetim Uygulamaları”. Muhasebe ve Denetime Bakış Dergisi, 119-136.

Covin, Jeffrey. G. and Slevin, Dennis. P. (1986). "The Development and Testing of An Organizational - Level Entrepreneurship Scale”, in Ronstadt, R. Et al. (Eds), Frontiers of Entrepreneurship Research, BabsonCollege, Wellesley, MA, 628-639.

Çalık, Temel. (2003). Performans Yönetimi Tanımlar, Kavramlar, İlkeler. Ankara: Gündüz Eğitim ve Yayıncılık.

Deshpande, Rohit. and Farley, John. U. (1998). "Measuring Market Orientation: Generalization and Synthesis". Journal Of Market Focused Management, 2, 213-232.

Elitaş, Cemal. ve Ağca, Veysel. (2006). "İşletmelerde Çok Boyutlu Performans Değerleme Yaklaşımları: Kavramsal Bir Çerçeve”. Afyon Kocatepe Üniversitesi, Sosyal Bilimler Enstitüsü Dergisi, 6(2), 344-370.

Ellinger, Alexander. E.; Daugherty, Patricia. J. and Keller, Scott. B. (2000). "The Relationship Between Marketing/LogisticsInterdepartmental Integration and Performance in U.S. ManufacturingFirms: An Empirical Study". Journal of Business Logistics, 21, 1-22.

Emerson, Carol. J. and Grimm, Curtis. M. (1996). "Logistics and Marketing Components of Customer Service: dan Emperical Test of the Mentzer, Gomes and Krapfel Model". International Journal of Physical Distribution \&Logistics Management, 26, 29-42.

Erserim, Alper. (2011). "Yönetim Muhasebesi Aracı Olarak Çok Boyutlu Performans Değerleme ve Örgüt Yapısı İlişkisi Üzerine Bir Araştırma”. Aksaray Üniversitesi İİBF Dergisi, 3(1), 21-33.

Garg, Vinay. K.; Walters, Bruce. A. and Priem, Richard. L. (2003). “Chief Executive Scanning Emphases, Environmental Dynamism, and Manufacturing Firm Performance”. Strategic Management Journal, 24, 725-744.

Gattorna, John; Day, Abby. and Hargreaves, John. (1991). "Effective Logistics Management". Logistics Information Management, 4 (2), 2-86.

Goll, Irene and Rasheed, Abdul. M. A. (1997). "Rational Decision Making and Firm Performance: The Moderating Role of Environment". Strategic Management Journal, 18(7), 583- 591.

Hult, G. Thomas. M.; Snow, Charles. C. and Kandemir, Destan. (2003). "The Role of Entrepreneurship in Building Cultural Competitiveness in Different Organizational Types". Journal of Mangement, 29(3), 401-426.

Morash, Edward. A.; Dröge, Cornelia. and Shawnee, Vckery. (1996)."Boundary-Spanning Interfaces Between Logistics, Production, Marketing And New Product Development”. International Journal of Physical Distribution \&Logistics Management, 26(8), 43-62.

Murphy, Paul R. and Poist, Richard F. (1996). "Comparative Views of Logistics And Marketing Practitioners Regarding Interfonctional Coordination”. International Journal of Physical Distribution \&Logistics Management, 26(8), 1528.

Neely, Andy and Adams, Crowe. (2001). “Perspectives On Performance: The Performance Prism”, Journal of Cost Management, 15(1), 7-15.

Neely, Andy; Adams, Chris and Crowe, Paul. (2001). "The Performance Prism in Practice”. Measuring Business Excellence, 5(2), 6-12.

Neely, Andy; Adams, Chris and Kennerley, Mike (2002a). "The Performance Prism: The Scorecard for Measuring and ManagingStakeholder Relationships", London: Financial Times/PrenticeHall.

Neely, Andy; Adams, Chris and Kennerley, Mike (2002b). "The Performance Prism: The Scorecard For Measuring and Managing Business Success". Pearson Education, 1-14.

Neely, Andy; Bourne, Mike and Kennerley, Mike (2000). "Performance Measurement System Design: Developing and Testing Process-Based Approach". International Journal of Operations \&Production Management, 20(10), 11191145 .

Nunnally, Jum. C. (1978). Psychometric Theory. McGraw-Hill. New York.

Öztürk, Ümit. (2009). Performans Yönetimi. İstanbul: Alfa Yayınları.

Parker, Charles. (2000). "Performance Measurement". Work Study, 49(2), 63-66.

Robinson, John. P.; Shaver, Phillip R. and Wrightsman, Lawrence S. (1991). Measures of and Social Psychological Attitudes, San Diego: Academic Press. 
Sarıkaya, Muammer (2011). "Paydaş Yaklaşımı Bağlamında İşletme-Paydaş Etkileşimi ve Stratejik Paydaş Analizi”. Ankara Sanayi Odası Yayın Organı, Eylül/ Ekim, 43-58.

Simmerly, Roy L. and Li, Mingfang. (2000). "Environmental Dynamism, Capital Structure and Performance: A Theoretical Integration and An Empirical Test”. Strategic Management Journal, 21, 31- 49.

Şentürk, Hulusi. (2005). Belediyelerde Performans Yönetimi. (2. Baskı). İstanbul: İlke Yayıncılık.

Tangen, Stefan. (2004). "Performance Measurement: From Philosophy to Practice".International Journal of Productivity and Performance Management, 53(8), 726-737.

Tınaz, Pınar. (2005). Çalışma Yaşamından Örnek Olaylar (1. Baskı). İstanbul: Beta Yayıncılık.

Türker, Duygu. (2009). "Measuring Corporate Social Responsibility: A Scale Development Study". Journal of Business Ethic, 85, 411-427.

Türk Dil Kurumu, Türkçe Sözlük,

http://tdkterim.gov.tr/bts/?kategori=verilst\&kelime=performans\&ayn=tam (28.10.2010).

Yazıcıoğlu, Yahşi ve Erdoğan, Samiye. (2004). SPSS Uygulamalı Bilimsel Araştırma Yöntemleri. Ankara: Detay Yayıncilık.

Yılmaz, Cengiz, Alpkan, Lütfihak ve Ergün, Ercan. (2005). "Cultural Determinants Of Customer and Learning-Oriented Value Systems and Their Joint Effects On Firm Performance”, Journal of Business Research, 58, 1340-1352.

Zahra, Shaker A. and Garvis, Dennis M. (2000). "International Corporate Entrepreneurship and Firm Performance: The Moderating Effect of International Environmental Hostility". Journal of Business Venturing, 15, 469- 492.

Zehir, Cemal ve Özşahin, Mehtap. (2006). "Stratejik Karar Verme Hızını Etkileyen Örgütsel, Çevresel Faktörler ve Firma Performansı İlişkisi: İmalat Sektöründe Bir Saha Çalışması”. Gazi Üniversitesi İktisadi ve İdari Bilimler Fakültesi Dergisi, 9(1), 137 - 157. 